\title{
A Survey in Prevalence of Anaemia in Adolescence Girls Eating Processed Food
}

\author{
Shubham Mohan Sharma, and Priyanka Sachdewa \\ Department of Community Medicine Shree Guru Gobind Singh Tricentary \\ University, Gurugram, Haryana, India \\ Corresponding author email: shubham_fmhs@sgtuniversity.org
}

\begin{abstract}
Anaemia is a medical condition which involves less number of red blood cells in blood. Person suffering from anaemia lack sufficient healthy blood cells in blood. In human beings, Red blood cells present in blood carry oxygen to other body tissues. Person suffering from anaemia feels tired and weak always because of less oxygen in body tissues. Few symptoms of anaemia include fatigue, skin pallor, and shortness of breath, light-headedness, dizziness or a fast heartbeat. The body requirement of iron in adolescent girl's is generally high, insufficient intake of iron results in anaemia. Current survey puts light on a factor which is not covered earlier, processed food use is increasing nowadays and regular eating affects eating habits in young age people a lot. The body requires healthy nutrients but it is replaced by processed food in young people. A close link of high intake of chemically processed food and nutrient deficiency in adolescent girls especially iron deficiency is observed.
\end{abstract}

\section{KEY WORDS: ANAEMIA, PROCESSED FOOD, HAEMOGLOBIN, IRON, RED BLOOD CELLS.}

\section{INTRODUCTION}

Anaemia is described as a deficiency of enough healthy red blood cells in blood. Red blood cells present in human blood works in transport of oxygen from lungs to rest of our body. Red blood cells also carry carbon-di-oxide from all our body to lungs. Later, lungs exhale out the carbon di oxide coming from cells. Generally, iron supplements are prescribed to anaemia patients. Role of iron in blood is, around $70 \%$ of total body iron level is found in the red blood cells of human blood called haemoglobin. Iron helps to convert blood sugar to energy. Iron boosts the immune system, aids cognitive function, supports healthy skin, hair and nails.

Haemoglobin, iron containing protein in the Red blood cells of blood of many animals. Haemoglobin transports oxygen to the tissues. Figure 1 shows uptake of oxygen by red blood

Biosc Biotech Res Comm P-ISSN: 0974-6455 E-ISSN: 2321-4007

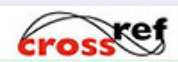

Identifiers and Pagination

Year: 2021 Vol: 14 No (6) Special Issue

Pages: $430-434$

This is an open access article under Creative

Commons License Attribn 4.0 Intl (CC-BY).

DOI: $h t t p: / / d x$.doi.org/10.21786/bbrc/14.7.90 cells and transfer of oxygen to the body tissue. Haemoglobin also forms an unstable bond with oxygen. The unstable bond of oxygen with haemoglobin is reversible. In the oxygenated state haemoglobin is called oxy haemoglobin. Oxy haemoglobin is bright red in colour. In the reduced state oxy haemoglobin is purplish blue. Haemoglobin is a protein made up of four polypeptide chains. Every polypeptide chain is attached to a heme group. Heme group is composed of porphyrin, porphyrin is attached to an iron atom. The iron-porphyrin complexes are responsible for the role of haemoglobin in oxygen transport in the blood.

When red blood cells die, haemoglobin breaks and iron is rescued. Later, iron is transported to the bone marrow. Transport of iron to bone marrow is done by proteins, transferrin.Transferrins are glycoprotein, transferrin glycoprotein is found in vertebrates. The role of transferrin is to mediate the transport of Iron $(\mathrm{Fe})$ through blood plasma. Transferrin is produced in the liver and contains binding sites for two Fe3+ atoms Iron is then used in the production of new red blood cells. Figure 2 shows the transfer of iron from cell to blood, iron then attaches with transferrin protein. Now, the remaining haemoglobin forms bilirubin. Bilirubin is a chemical excreted into the bile and gives the faeces a yellow-brown colour.
Article Information

Received: $11^{\text {th }}$ May 2021

ccepted after revision: $20^{\text {th }}$ July 2021 
Figure 1: Figure showing oxygen getting attached to Red blood cells of blood and release of oxygen from Red blood cells (Dayyal Dg et. al.)

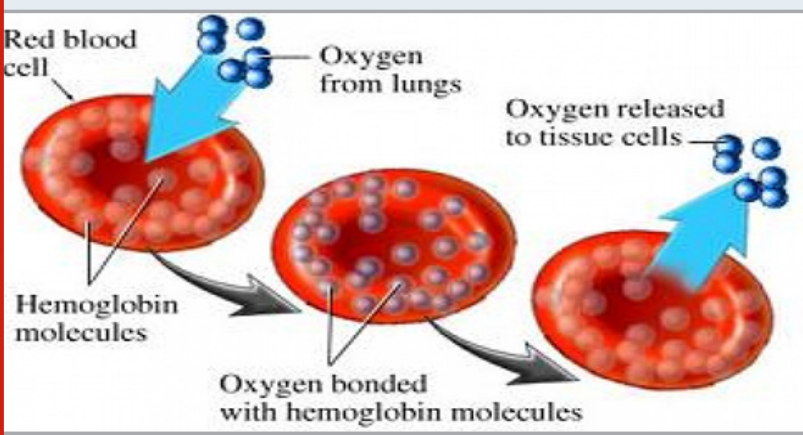

Figure 2: Transfer of iron from cell to blood. (M. S. James Baggott et. al.)

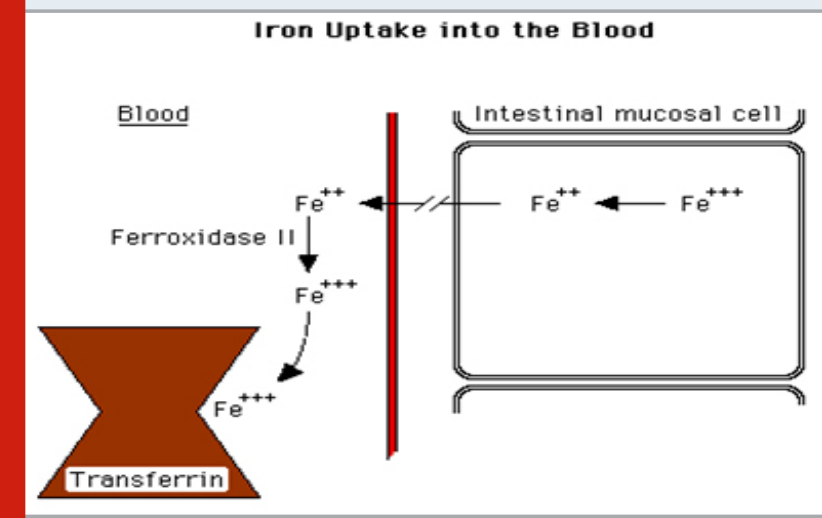

Figure 3:Structure of Oxy-haemoglobin and Deoxyhaemoglobin(C.C. Pauling L et. al.)

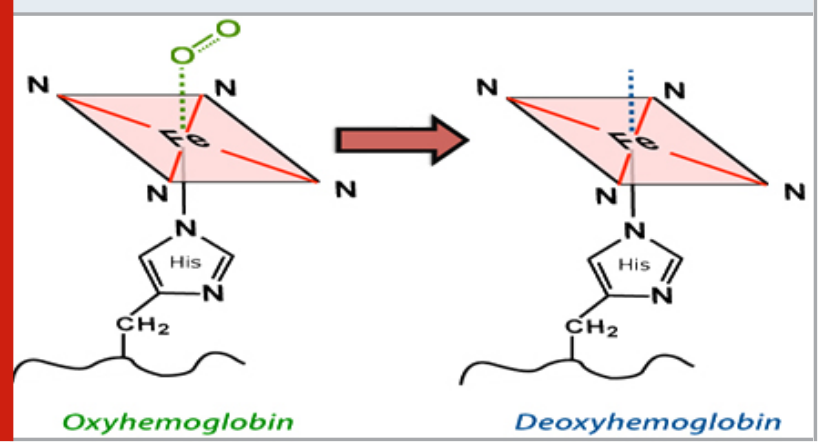

Haemoglobin molecule contains heme and globin. Four hemegroups surround a globin group and form a tetrahedral structure. Heme group is composed of porphyrin, Porphyrin is a ringlike organic compound.A porphyrin is a large ring organic compound consisting of 4 pyrroles. Pyrroles are small ring compound made up of 4 carbon and 1 nitrogen atom. A large pyrrole molecule is formed of series of single and double bonds connected together. Iron atom is attached with porphyrin. Oxygen is attached with the iron atom in haemoglobin, as the blood travels between the lungs and the tissues. Haemoglobin contains four iron atoms. Every iron atom can bind with one atom of oxygen. Figure 3 shows the structure of oxy-haemoglobin and haemoglobin molecule without oxygen. Table 1 shows the components of human blood and Figure 4 shows the cross section view of human artery.

Table 1. The components of human blood (Hemoglobin et. al. (2020)

\begin{tabular}{|l|l|}
\hline Components of blood & Description of blood components \\
\hline Plasma & $\begin{array}{l}\text { Plasma mainly contains water. Salts, lipids, } \\
\text { hormones especially proteins are present in } \\
\text { blood. }\end{array}$ \\
\hline Red blood cells & $\begin{array}{l}\text { Red blood cells contain haemoglobin. } \\
\text { Haemoglobin is a protein, carries oxygen } \\
\text { from lungs to all body parts. Body cells use } \\
\text { oxygen to produce energy required for } \\
\text { functioning and releases carbon di oxide. } \\
\text { Haemoglobin also gives red colour to blood }\end{array}$ \\
\hline White blood cells & $\begin{array}{l}\text { White blood cells are a major component of } \\
\text { human body's immune system. White } \\
\text { blood cell count is also linked with } \\
\text { infection in body and inflammatory } \\
\text { diseases, leukaemia and bone marrow } \\
\text { disorders. Figure 4 shows a cross section } \\
\text { view of human artery. }\end{array}$ \\
\hline Platelets & $\begin{array}{l}\text { Platelets have no cell nucleus. Platelets are } \\
\text { fragments of cytoplasm. Platelets are } \\
\text { derived from bone marrow. Platelets then } \\
\text { enter the circulation. }\end{array}$ \\
\hline
\end{tabular}

Figure 4: The cross section view of human artery(David Zieve et. al.).

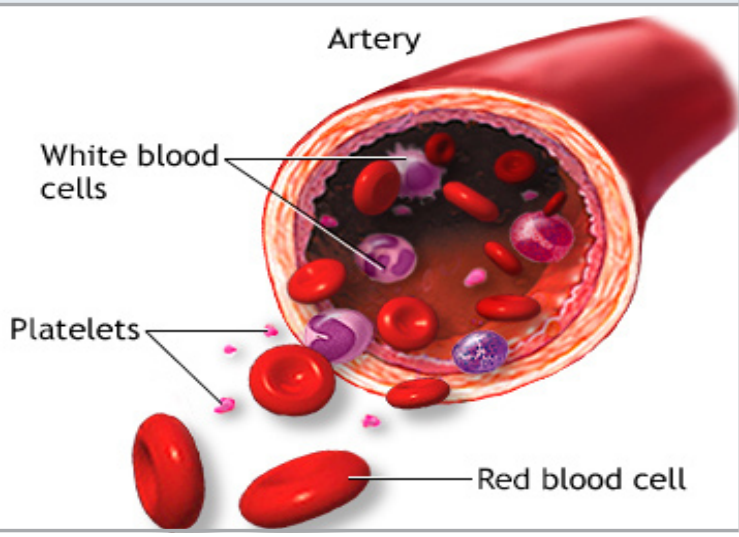

Food that is already cooked, canned food, frozen food, packaged food, baked, dried or when the nutritional composition of food is changed with fortifying, preserving or preparing in different ways. Salt, sugar and fat added in processed food as a preservative lead to people eat more calories than the recommended amount of sugar, salt and fat in their diet. People eating processed food are not aware that how much extra salt, sugar, fat has been added to the food they are buying and eating. Processed foods are also higher in calories due to the high amounts of added sugar and fat in them. Table 2 shows the variety of commonly used processed food available in the market(A. Amy richer Smith, Jennifer Fox (2020), J Maldonado).

The present study suggests the effect of eating processed food and how the regular intake of eating processed food 
is linked with prevalence of anaemia in adolescent girls belonging to different socio-economic status, how the presence of high calories and preservatives add more energy to the food and ultimately restrict adolescent girls in adapting healthy eating habits.

Table 2. shows the variety of processed food available in the market.

\begin{tabular}{|c|l|}
\hline Processed food & Variety available in the market \\
\hline 1. Breakfast cereals: & Corn flakes, ready to eat food, jam, ketchup \\
\hline 2. Cheese: & Flavoured cheese spread. \\
\hline 3. Tinned fruits / Vegetables: & $\begin{array}{l}\text { Vegetables canned in sugar solution, } \\
\text { antioxidants and acidity regulators to } \\
\text { prevent fruits/vegetables from getting } \\
\text { rotten. Added preservatives not only } \\
\text { decreases the nutritional value of food but } \\
\text { also causes harmful effects on the person } \\
\text { consuming it regularly. }\end{array}$ \\
\hline 4. Snacks: & $\begin{array}{l}\text { A variety of snacks are available in the } \\
\text { market now a days. Snacks include chips, } \\
\text { biscuits, cookies, flavoured fryums, desserts } \\
\text { and traditional canned sweets. }\end{array}$ \\
\hline 5. Microwave meals or ready meals: & $\begin{array}{l}\text { Microwave meals need last minute heating } \\
\text { in microwave and are highly preferred }\end{array}$ \\
\hline 6. Cake and biscuits: & $\begin{array}{l}\text { Chocolate, strawberry, butterscotch, and } \\
\text { many more flavour and varieties of cakes } \\
\text { and biscuits are available. }\end{array}$ \\
\hline 7. Drinks: & $\begin{array}{l}\text { Sweetened fruit juice, aerated soft drinks, } \\
\text { shakes, coffee, flavoured milk. }\end{array}$ \\
\hline
\end{tabular}

Research Question: What is the effect of processed food in prevalence of anaemia adolescent girls?

Review Of Literature: Helen Freitas et al. conducted a study on the energy intake from ultra-processed food in adolescent, the study majorly focused on the fact that adolescents belonging to good socio-economic status eat more ultra-processed food and adolescents belonging to poor socio-economic status eat less processed food. The study was not focussed on relating the link between eating processed food and prevalence of diseases in adolescent girls (H.F.D'avila et. al. (2017) D Raghunatha Rao et al.conducted a survey to analyse the nutritional knowledge and dietary habits of adolescent girls, the study later focuses on educating the school girls about healthy eating habits. The survey lacks in providing the link between high intake of processed food and anaemia prevalence in adolescent girls (D. Raghunatha Rao et. al. (2007) Justin R et al. conducted a survey on dietary potassium and sodium intake in adolescent girls and the link of high sodium and potassium intake with high blood pressure in adolescent girls. The survey does not covers link between high sodium and potassium intake with anaemia prevalence in young girls (J.R. Buendia et. al. (2015).

\section{METHODOLOGY}

Design: The survey involves 90 samplesof adolescent age group. As per World health organization, WHO, the adolescent age group ranges from 10 to 19 years. In current survey, the adolescent age group is divided into three sub groups A, B and C.
A. Early age group
B. Middle age group
C. Late age group

Early age adolescent group A comprises girls of 10 to 13 years. Middle age adolescent group B includes girls of 13 years to girls of 16 years. $\mathrm{C}$ group covers girls ranging from 16 years to 19 years of age. Late age adolescent group is the $\mathrm{C}$ group. The survey on prevalence of anaemia in adolescent girls belonging to $\mathrm{A}, \mathrm{B}$ and $\mathrm{C}$ sub group eating chemically processed food is done on three different parameters of economic background. Girls belonging to low income group are taken together. Girls belonging to middle income group are grouped together and the group of girls belonging to upper middle class are analysed together.

Low income group:Low income group includes adolescent girls residing in slum area. Slum area is mostly closely packet area where a large number of population is residing. Low income group adolescent girls residing in slum area are generally devoid of proper food required for health and growth of adolescent. Proper sanitization and education about healthy food is not available for low income adolescent girls. Importance of balanced diet is also not known to girls of low income group.

Middle income group: Middle income group includes adolescent girls residing in societies, flats and area having better sanitization. Middle income group resides mostly in less closely packet area and place where relatively less number of population is residing. Middle income group adolescent girls are not devoid of proper food required for health and growth. Middle income group adolescent girls know the importance of balanced diet. Importance of balanced and healthy diet is provided in schools and through other modes of media also - newspapers, television, radio, internet and many other High income group: High income group includes adolescent girls residing in big societies, bungalows and in area having very good sanitization. High income group resides in big area where very less number of population is residing. High income group adolescent girls are not devoid of proper food required for health and growth. High income group adolescent girls know the importance of balanced diet. Importance of balanced and healthy diet is provided in schools and through other modes of media also - newspapers, television, radio, internet and many other.

\section{RESULTS AND DISCUSSION}

A survey is conducted on 90 adolescent girls belonging to different age group $\mathrm{A}$ is early adolescent girls group 10 to 13 years of age, B group is of middle age group includes 13 to 16 years old girls and $\mathrm{C}$ group involves girls from 16 years to 19 years. Table 3 shows the average haemoglobin count of 10 girls belonging to A group, 10 to 13 years and percentage of eating processed food in a day, low income group girls showed less packaged food eating habit whereas middle and high income group girls showed high packed food eating habit. Table 4 shows the average result of haemoglobin of 10 candidates in B group adolescent girls 13 to 16 years and the average eating of packed food in a day. In B group 
low income group adolescent girls showed less packed food eating habit. Table 5 shows average result of haemoglobin of 10 candidates in $\mathrm{C}$ group adolescent girls, 16 to 19 years of age and percentage packed food eating habit in a day. $\mathrm{C}$ group adolescent girls also showed less packed food intake by low income group and very high intake of packed food in a day by medium and high income group.

Table 3. Average result of haemoglobin of adolescent girls of groupA i.e. 10-13 years / early adolescent and percentage eating of processed food.

\begin{tabular}{|l|c|c|}
\hline Income group & $\begin{array}{c}\text { Average Haemoglobin } \\
\text { count of } \mathbf{1 0} \\
\text { candidates }\end{array}$ & $\begin{array}{c}\text { Eating habits } \\
\text { (Percentage eating of } \\
\text { processed food) }\end{array}$ \\
\hline Low income group & 9 & $38 \%$ \\
\hline Middle income group & 10.5 & $77 \%$ \\
\hline High income group & 10 & $81 \%$ \\
\hline
\end{tabular}

Table 4. Average result of haemoglobin of adolescent girls of group B i.e. 13-16years' adolescent and percentage eating of processed food.

\begin{tabular}{|l|c|c|}
\hline Income group & $\begin{array}{c}\text { Average Haemoglobin } \\
\text { count of 10 } \\
\text { candidates }\end{array}$ & $\begin{array}{c}\text { Eating habits } \\
\text { (Percentage eating of } \\
\text { processed food) }\end{array}$ \\
\hline Low income group & 10 & $45 \%$ \\
\hline Middle income group & 9.5 & $80 \%$ \\
\hline High income group & 10 & $89 \%$ \\
\hline
\end{tabular}

Table 5. Average result of haemoglobin of adolescent girls of group C i.e. 16-19 years and percentage eating of processed food.

\begin{tabular}{|l|c|c|}
\hline Income group & $\begin{array}{c}\text { Average Haemoglobin } \\
\text { count of 10 } \\
\text { candidates }\end{array}$ & $\begin{array}{c}\text { Eating habits } \\
\text { (Percentage eating of } \\
\text { processed food) }\end{array}$ \\
\hline Low income group & 14.5 & $40 \%$ \\
\hline Middle income group & 11 & $88 \%$ \\
\hline High income group & 12 & $90 \%$ \\
\hline
\end{tabular}

\section{CONCLUSION}

The survey conducted shows that girls belonging tolow income group with less percentage of processed food intake showed high haemoglobin. Whereas, girls belonging to middle income group and high income group even having education about healthy eating habits showed less haemoglobin count. The reason behind low haemoglobin count of middle and high income group, as discussed with every candidate is observed as high intake of processed food. The high sodium and added sugar present in processed food provides instant energy and because of good taste, person eat it again and again, as a result lack of essential nutrients required for the growth of adolescent.

\section{REFERENCES}

Al-Harbi, N., Alrasheedi, M.S. and Alshammari, S.T.,
2020. Hemoglobin level is associated with severe stroke among stroke patients in Saudi Arabia. International Journal of Health Sciences, 14(5), p.18.

Buendia, J.R., Bradlee, M.L., Daniels, S.R., Singer, M.R. and Moore, L.L., 2015. Longitudinal effects of dietary sodium and potassium on blood pressure in adolescent girls. JAMA pediatrics, 169(6), pp.560-568.

D'Avila, H.F. and Kirsten, V.R., 2017. Energy intake from ultra-processed foods among adolescents. Revista Paulista de Pediatria, 35, pp.54-60.

Pathuri, N.K., Vasireddy, G., Chelimela, D., Varahala, A.M. and Nagamuthu, E.A., 2018. Attitude And Outlook Of Medical And Non-Medical Students Towards Blood Donation-A Study In Telangana State. Journal Of Evolution Of Medical And Dental Sciences-Jemds, 7(25), 
pp.2944-2948.

Prusty, S.K. and Sahu, P.K., 2020. A Survey on the Prevalence of Anaemia in Pregnant and Lactating Women Eating Processed Food. Journal of Pharmaceutical Research International, pp.95-101.

Prusty, S.K. and Sahu, P.K., 2020. A Survey on the Prevalence of Anaemia in Pregnant and Lactating Women Eating Processed Food. Journal of Pharmaceutical Research International, pp.95-101.
Prusty, S.K. and Sahu, P.K., 2020. A Survey on the Prevalence of Anaemia in Pregnant and Lactating Women Eating Processed Food. Journal of Pharmaceutical Research International, pp.95-101.

Rao, D.R., Vijayapushpam, T., Rao, G.S., Antony, G.M. and Sarma, K.V.R., 2007. Dietary habits and effect of two different educational tools on nutrition knowledge of school going adolescent girls in Hyderabad, India. European journal of clinical nutrition, 61(9), pp.10811085. 